\title{
Agnieszka Loza, Paweł Beyga, Zaraza w Kościele, wyd. Leksem Studio, Żmigród 2021, ss. 169
}

Głośnym echem w 1985 roku odbił się Raport o stanie wiary — wywiad-rzeka z kardynałem Josephem Ratzingerem, przeprowadzony przez Vittoria Messoriego. Raport opisuje stan Kościoła katolickiego po II Soborze Watykańskim. Ratzinger odnosi się w wywiadzie krytycznie m.in. do tzw. hermeneutyki zerwania pomiędzy Kościołem przedsoborowym a posoborowym.

Za raport o stanie Kościoła w Polsce w czasie pandemii koronawirusa można uznać książkę Agnieszki Łozy i Pawła Beygi Zaraza w Kościele. Autorzy młodzi, choć nie gniewni, lecz zatroskani o przyszłość Kościoła teologowie nie piszą o nim z zewnątrz, lecz z wewnątrz, będąc zaangażowanymi na ważnym dla Kościoła polu, jakim jest nauczanie religii w szkole. Autorzy Zarazy w Kościele zrobili doktoraty z teologii: Agnieszka Łoza pt.: Logos jako zasada hermeneutyczna $w$ teologicznej refleksji nad nowym ateizmem, a Paweł Beyga: Problem tradycji anglikańskiej $w$ mszale dla ordynariatów personalnych dla bytych anglikanów.

Na zarazę w Kościele w Polsce Autorzy patrzą z perspektywy Wrocławia, który stał się głośny za sprawą afery kardynała Gulbinowicza. Wrocław doświadczył czarnego humoru, polegającego na wydobywaniu efektów humorystycznych z zestawienia elementów grozy i absurdu. Ten czarny humor zawiera anegdota opowiedziana przez kardynała Ratzingera w wywiadzie przeprowadzonym z nim przez Petera Seewalda. Anegdota głosi, jakoby Napoleon miał kiedyś powiedzieć, że zmiecie Kościół z powierzchni ziemi. Na co pewien kardynał odrzekł: „Nawet nam nie udało się tego dokonać”.

Autorzy wobec sytuacji Kościoła w Polsce nie chowają głowy w piasek, czyli nie przyjmują postawy udawania, że nie ma tego, co kłopotliwe, groźne lub przy- 
kre, by w konsekwencji uciec przed odpowiedzialnością. Ten osobliwie malowniczy rzekomy strusi zwyczaj jest trudny do uzasadnienia. Wszystko bowiem przeciw niemu przemawia. Ale unikanie trudnych decyzji jest tak kuszące, a tchórzliwość, lenistwo lub naiwny optymizm są tak duże, że człowiek godzi się nawet na piasek w oczach i w ustach. Taka postawa chowania głowy w piasek kusi wobec zarazy w Kościele.

Zaraza $\mathrm{w}$ dosłownym znaczeniu, czyli choroba zakaźna występująca w masowej skali na jakimś terenie, jest niebezpieczna dla życia. Współczesna zaraza koronawirusa okazała się nie tylko niebezpieczna dla życia człowieka, ale doprowadziła do lockdownu gospodarki, społeczeństwa oraz Kościoła. Zaraza może być również rozumiana jako metafora, która polega na przenoszeniu słowa oznaczającego jakąś rzecz na określenie innej rzeczy. Współczesna zaraza została określona mianem koronawirusa. Nazwa ta zawiera dwa łacińskie wyrazy: corōna, czyli wieniec, oraz vīrus, czyli jad — sok trujący lub śmierdzący. Zaraza w odniesieniu do Kościoła jest jadem go zatruwającym. Tym jadem jest korupcja grzechu, dzięki której najpiękniejsze ideały głoszone przez Kościół osiągają swoje zaprzeczenie w życiu wszystkich jego członków, poczynając od papieża, przez kardynałów i biskupów, a kończąc na ostatnim wiernym świeckim. Wskutek erupcji grzechu ideały sięgają bruku.

W publikacji Zaraza w Kościele można wyróżnić dwie warstwy. Pierwsza ukazuje zarazę koronawirusa jako wyzwanie dla Kościoła, a druga - duchową zarazę będącą jadem zatruwającym Kościół od wewnątrz.

Koronawirus jest wyzwaniem dla teologii. Musi ona podjąć próbę odpowiedzi na pytanie: dlaczego Bóg dopuszcza cierpienie? Z faktu istnienia cierpienia ateizm formułuje koronny argument przeciwko istnieniu Boga. Zaraza zdaje się jednak sprzyjać nie tylko ateizmowi, lecz także fideizmowi, który głosi prymat wiary nad poznaniem rozumowym, a w konsekwencji teoriami naukowymi. Fideizm jest co najmniej bezmyślnością w stosunku do prawd wiary. Koronawirus sprzyja także doketyzmowi głoszącemu, że Jezus Chrystus nie miał prawdziwego ciała ludzkiego, ale ciało pozorne. Chrześcijaństwo jako religia Wcielenia wyklucza wszelkie pozory. Dotyczy to przede wszystkim sakramentów świętych jako widzialnych znaków niewidzialnej łaski oraz kościelnej communio, którą one budują. Wszelki zatem dystans od materii sakramentu i szafarza jest sakramentalnym doketyzmem. Również kościelna communio nie może podlegać lockdownowi. Nie ma tej communio, gdy stosuje się zasadę „człowiek człowiekowi koronawirusem". Ta zasada rodzi eklezjalny doketyzm. Sakramentalno-eklezjalny doketyzm uderza w liturgię. Przykładem liturgicznego doketyzmu jest tele-liturgia, czyli transmisja nabożeństw. Tele-liturgia pokazuje widzialny znak sakramentu, który nie jest jednak skutecznym przekaźnikiem łaski dla oglądających go w telewizji czy Internecie. Tele-liturgistami nie byli męczennicy z Abiteny - nie przez brak dostępu do telewizji czy Internetu, ale dzięki zasadzie: 
„Sine dominico non possumus” (bez niedzieli nie możemy). Koronawirus stał się również wyzwaniem pastoralnym. $Z$ pasterzy mających oddawać życie za owce uczynił najemników zabarykadowanych w swoich pałacach i rządzących za pomocą dyspens. Mogą one rodzić problemy dyscyplinarne: skoro można dyspensować od mszy, dlaczego nie można dyspensować od celibatu?

$\mathrm{Z}$ zarazą koronawirusa zbiegła się zaraza w polskim Kościele. Przybiera ona postać brudu w Kościele, o którym mówił kardynał Ratzinger w czasie drogi krzyżowej w Colosseum w 2005 roku: „Czy jednak nie powinniśmy myśleć także o tym, ile Chrystus musi wycierpieć w swoim Kościele? Ile brudu jest w Kościele, i to właśnie wśród tych, którzy poprzez kapłaństwo powinni należeć całkowicie do Niego!".

Parasol Jana Pawła II nie uchronił od tych brudów Kościoła katolickiego w Polsce. Objawiły się one z całą mocą w czasie zarazy koronawirusa. W ciągu 16 lat od śmierci Jana Pawła II kryzys Kościoła w Polsce dojrzewał. Ten kryzys oddaje szereg paradoksów, czyli pozornie niemożliwych sytuacji, w których współistnieją dwa wykluczające się fakty. Entuzjazm wobec Jana Pawła II sięgający zenitu w jakimś janopawłowym festiwalu i równocześnie wzrastająca krytyka Jana Pawła II zmierzająca do wygaszenia jego kultu. Wyrosłe jak grzyby po deszczu pomniki Jana Pawła II stają się przedmiotem profanacji. Kościół, będący świadkiem wolności, a równocześnie postrzegany w miejscu, w którym kiedyś stało ZOMO. W czasie statio orbis Kongresu Eucharystycznego we Wrocławiu Jan Paweł II powiedział: „Usiłuje się bowiem dzisiaj wmówić człowiekowi i całym społeczeństwom, iż Bóg jest przeszkodą na drodze do pełnej wolności — że Kościół jest wrogiem wolności, że wolności nie rozumie, że się jej lęka. Jest tutaj jakieś niesłychane pomylenie pojęć! Kościół bowiem nie przestaje być w świecie głosicielem ewangelii wolności! To jest jego misja. «Ku wolności wyswobodził nas Chrystus» (Ga 5,1)!”.

Jednak pedofilia będąca przemocą wobec dzieci jest przeciwieństwem Ewangelii wolności. Tłumy młodzieży otaczające Jana Pawła II i równocześnie młodzież opuszczająca masowo Kościół po przyjęciu sakramentu bierzmowania i robiąca thum na strajku kobiet. „Bierzmowanie dziejów” w Krakowie na zakończenie pierwszej pielgrzymki Jana Pawła II do Polski i apostazja dziejów, objawiająca się profanacją świątyń. Wejście lekcji religii do szkół i niejako samoistne wyjście tych lekcji ze szkół, bez stosowania środków administracyjnych. To tylko niektóre paradoksy, o których piszą Autorzy Zarazy w Kościele. Zauważone paradoksy wskazują na złą zmianę w Kościele katolickim w Polsce i wokół niego. Ta zła zmiana rodzi pytania: dlaczego? i co dalej? Odpowiedź na te pytania mogłaby przynieść kolejne dwa tomy po Zarazie w Kościele.

Zaraza w Kościele wywołała w nim kryzys. W języku potocznym słowo kryzys służy określaniu różnych sytuacji, których wspólnym mianownikiem jest aspekt zagrożenia. Grecka etymologia tego pojęcia nie wskazuje jednak na jego 
pejoratywny charakter. Grecki rzeczownik krisis oznacza bowiem wybór, rozstrzygnięcie, czyli przesilenie, punkt zwrotny, wstrząs, przełom. Ten przełom, punkt zwrotny w przypadku Kościoła jest w rękach Bożej Opatrzności, która jednak chce współpracy ludzi. Tę współpracę może zainicjować dyskusja nad zarazą w Kościele. Recenzowana książka jest ważnym przyczynkiem do tej dyskusji. Nie powinna ona przejść bez echa, tak jak bez echa przeszła książka Antonia Rosminiego O pięciu ranach Kościoła świętego napisana w 1848 roku. Był to raport o stanie ówczesnego Kościoła, który też nie był wolny od kryzysu. Ten kryzys widział Rosmini m.in. w odebraniu prezbiterom i wiernym świeckim prawa do wyboru swoich biskupów czy też w zbytnim zniewoleniu dobrami kościelnymi oraz „duchem feudalizmu”. Nikt jednak nie chciał dyskutować z Rosminim. $Z$ powodu opisania kryzysu ówczesnego Kościoła jego dzieło znalazło się w 1849 roku na indeksie ksiąg zakazanych. Książka Zaraza w Kościele, czyli raport o brudach i ranach polskiego Kościoła, jest apelem o przerwanie zabawy na tonącym Titanicu, który dzisiejszy Kościół w Polsce przypomina. Jest to jednak Kościół Jezusa Chrystusa, a nie ludzi, jak raportował kardynał Ratzinger w 1985 roku. Jednak to ludzie wywołują w nim kryzys, dokumentowany przez dzieło O pięciu ranach Kościoła świętego Rosminiego, Raport o stanie wiary Ratzingera czy Zaraze w Kościele Agnieszki Łozy i Pawła Beygi. Kościół po koronawirusie musi być ten sam, tak jak jego głowa - Jezus Chrystus, „wczoraj i dziś, ten sam i na wieki” (Hebr 13,8). A równocześnie musi być inny w ludziach będących członkami Ciała Chrystusa. Nie będzie to jednak nigdy Kościół bez kryzysu wywołanego erupcją grzechu, o którym marzyli donatyści, nowacjanie czy Joachim z Fiore. Według Benedykta XVI ,zło zawsze będzie częścią tajemnicy Kościoła”, bo jest on przecież dla grzeszników, by w nim stawali się świętymi.

ks. prof. dr hab. Bogdan Ferdek ${ }^{1}$ Papieski Wydział Teologiczny we Wrocławiu

1 Bogdan Ferdek SThD — born on June 22, 1956 in Ozimek. Lecturer in dogmatic theology at the Pontifical Faculty of Theology in Wrocław. Member of the: Theological Sciences Committee, Polish Academy of Sciences; the Society of Dogmatics Theologians, Polish Mariological Society; the Polish Section of the Bonhoeffer Society, and a consultant of the Committee for the Doctrine of the Faith of the Polish Episcopate. Author of the following publications: Zukunft als theologisches Problem (2000), Teologiczna futurologia (2001), Eschatologia Taboru (2005), Nasza Siostra Córa i Matka Pana (2007). Co-organizer of Christological conferences in cooperation with the Faculty of Theology, Adam Mickiewicz University in Poznań, as well as philosophical and theological conferences in cooperation with the Institute of Philosophy, Wroclaw University; e-mail: bferdek@pwt.wroc.pl. ORCID: 0000-0001-5787-0523. 


\section{Summary}

In the opinion of Bogdan Ferdek, the new book of Agnieszka Łoza and Paweł Beyga is a special theological report on the state of the Church in Poland. During the pandemic time since 2021 the Catholic Church has had to search for solving problems in the Christian community. According to the authors of this new book, in the Polish Catholic Church two kinds of problems can be discovered. Firstly, there is a problem with morality among the clergy, the problems of sexual abuse and teaching the Catholic religion in Polish schools. Conversely, there is a problem related to the secularization of Polish people. Bogdan Ferdek in his review showed that the new book of two young Polish theologians is an answer to very important questions in the Polish Christendom in the time of the pandemic.

\section{Keywords}

plague in the Church, pandemic, theologians, Poland

\section{Slowa kluczowe}

zaraza w Kościele, pandemia, teologowie, Polska 